\title{
SEISMIC BEHAVIOUR OF LA MERCED TEMPLE IN MORELIA, MEXICO
}

\author{
LIDIA MEJIA ${ }^{1}$, GUILLERMO MARTINEZ ${ }^{1 *}$, BERTHA OLMOS ${ }^{1}$ AND JOSE \\ MANUEL JARA ${ }^{1}$ \\ ${ }^{1}$ Civil Engineering Department \\ Universidad Michoacana de San Nicolás de Hidalgo (UMSNH) \\ Av. Gral. Francisco J. Mújica S/N, Felcitas del Río, 58004 Morelia, Mich., Mexico \\ e-mail: guillermo.martinez@umich.mx (*corresponding author) \\ email: \{lidiamejiaolmos, ba.olmos, jmjara70\}@gmail.com
}

Keywords: Macroelement, Earthquake, Nonlinear Analyses, Masonry

\begin{abstract}
This paper studies the seismic behaviour of La Merced temple, dating from the beginning of s. XVII and is located in the historic center of the city of Morelia considering a set of 9 real September 19, 2017, earthquake acceleration records obtained in seismic stations located near the epicenter, which were used without any scaling factor and then applying a scaling factor to reach the site maximum expected peak ground accelerations for probabilistic return periods of 475 years and 975 years.
\end{abstract}

\section{INTRODUCTION}

The temple of La Merced in the historic center of the city of Morelia, Mexico, is located with coordinates $19^{\circ} 42^{\prime} 10^{\prime \prime} \mathrm{N}, 101^{\circ} 1149^{\prime \prime} \mathrm{W}$, Figure 1a, which, as seen in Figure 1b, adjoins to the David G. Berlanga elementary school, which was formerly part of the conventual structure. At the end of the 16th century the Order of Nuestra Señora de la Merced settled in New Spain, which throughout the first century of colonial life had stood out in a remarkable way due to the fact that its friars were part, by generally, of the army of conquerors, in which they normally functioned as chaplains [1]. In 1604, Mercedarian friars Pedro de Burgos and Álvaro García obtained a license from Viceroy Luis de Velasco and Bishop Juan Fernández Rosillo to found a convent in the city of Valladolid, now Morelia, for which they acquired a house owned by Melchor Pardo and his wife María Ortega, to which they later added two adjacent pieces of land donated by the City Council. The founding friar of the convent, Felipe Gutiérrez, began the work of the church and convent with the alms of the neighbors. However, in 1606, at the death of Bishop Fernández Rosillo, the vacant headquarters council issued a suspension order of the work trying to avoid the convent foundation. The mercedarios went for their defense before the viceroy and subsequently obtained the support of the new bishop Friar Baltazar de Covarrubias, who endorsed the respective license and suspended the Cabildo's order; the work resumed around 1608-1609, under the direction of the new prior of the convent Friar Andrés de la Fuente 
[1]. The religious order of La Merced was the one that suffered the most economic difficulties in the city, the most difficult situation for which the temple was concluded in 1736 with the construction of its east or main façade, which at the day, retains its original door.
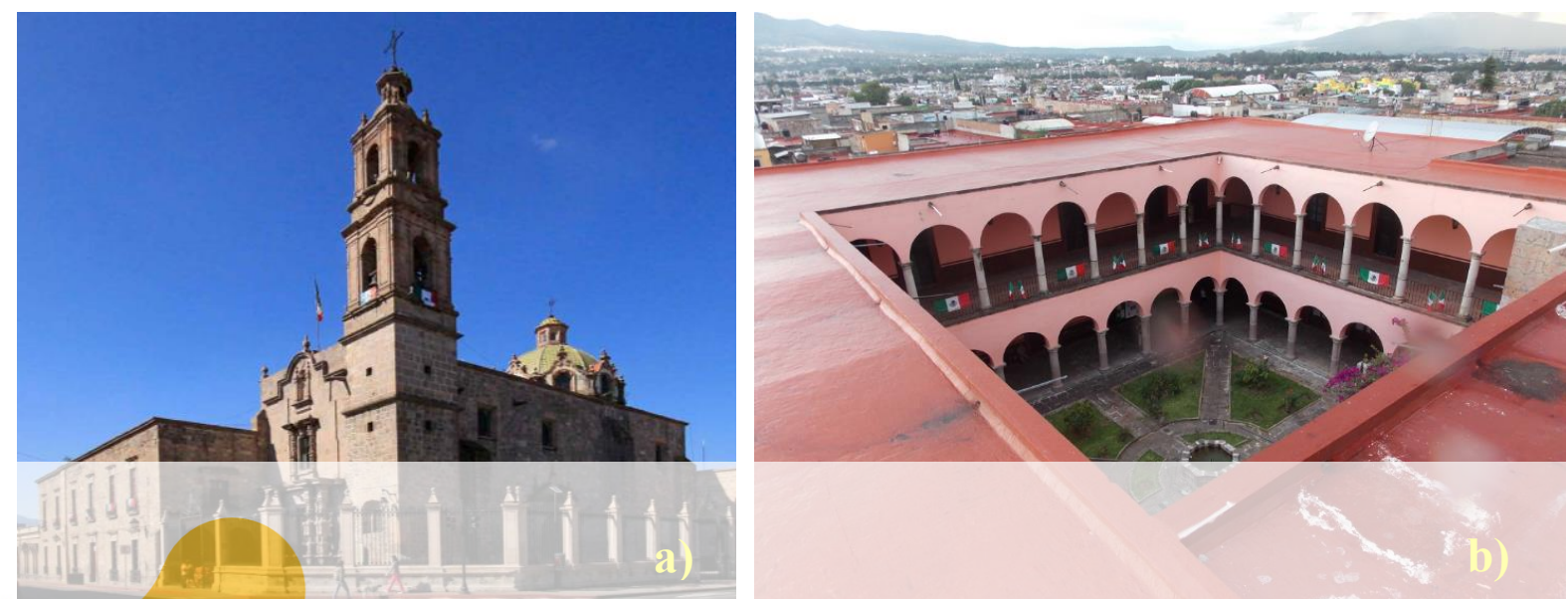

Figure 1: a) La Merced church. b) old convent cloister today David G. Berlanga elementary school

\section{ARCHITECTONIC CHARACTERISTICS}

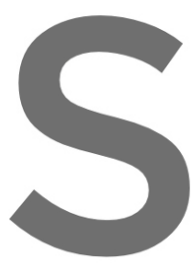

The church has two the 18 th century and the stiffened by two buttres

and is attached to the $\mathrm{m}$ and rests on an octagonal drum
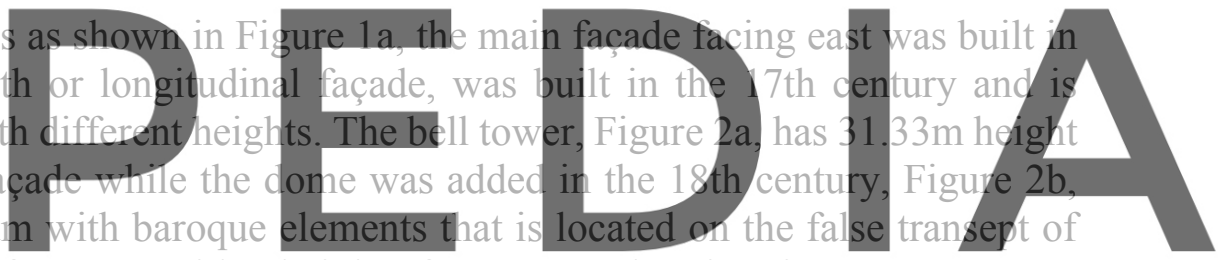

the nave which has a length of $35.39 \mathrm{~m}$ with a height of $13.04 \mathrm{~m}$ and an-interior $6.69 \mathrm{~m}$ span as

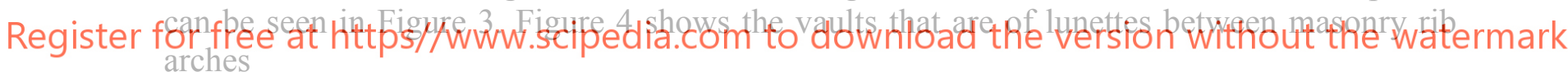
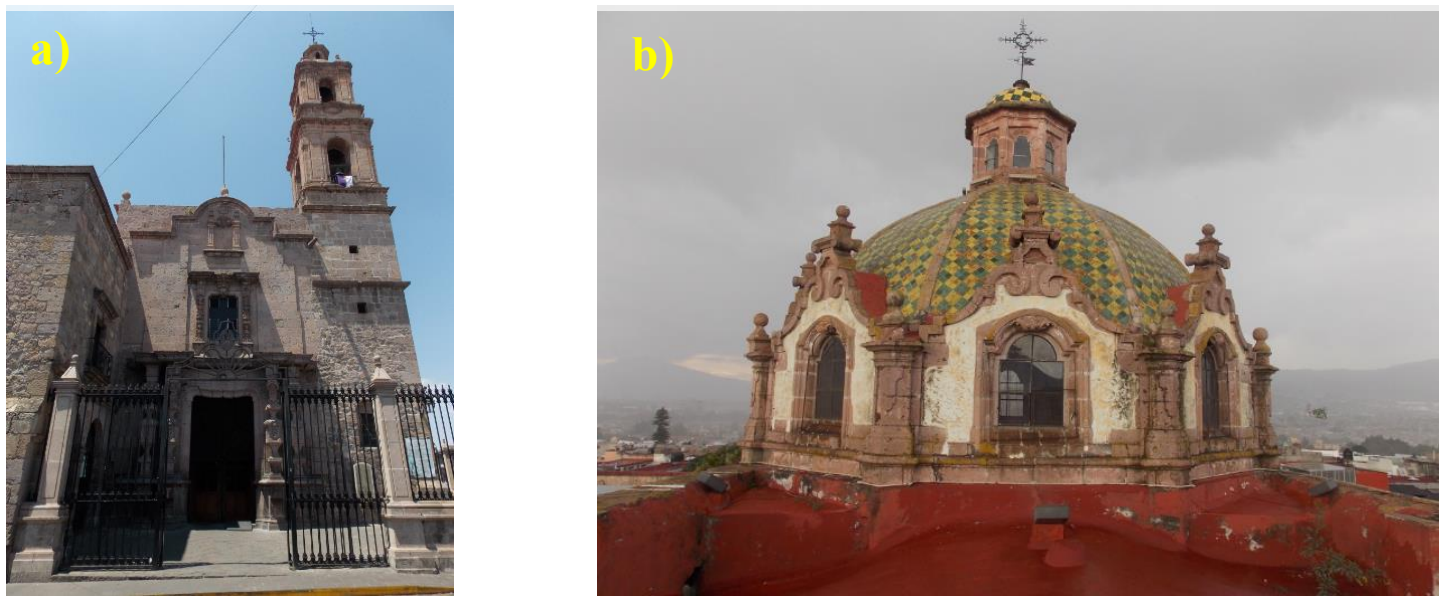

Figure 2: a) Bell tower and east façade, b) XVIII century dome. 

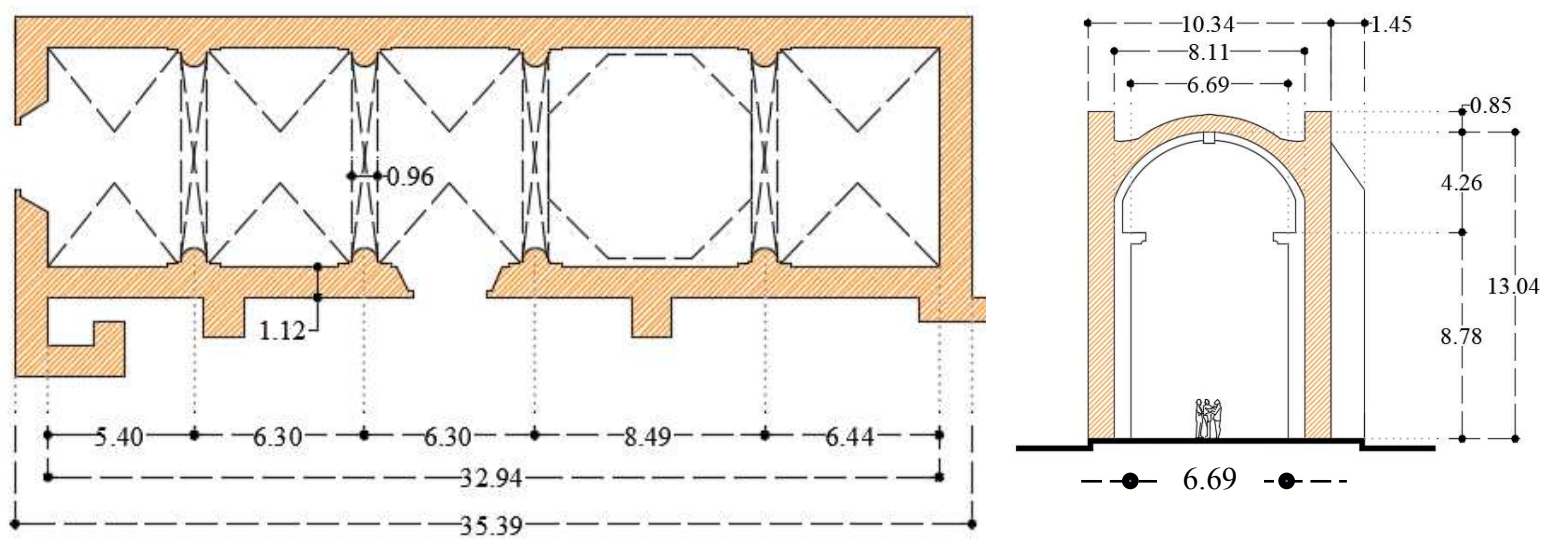

Figure 3: Nave plan view and transversal section

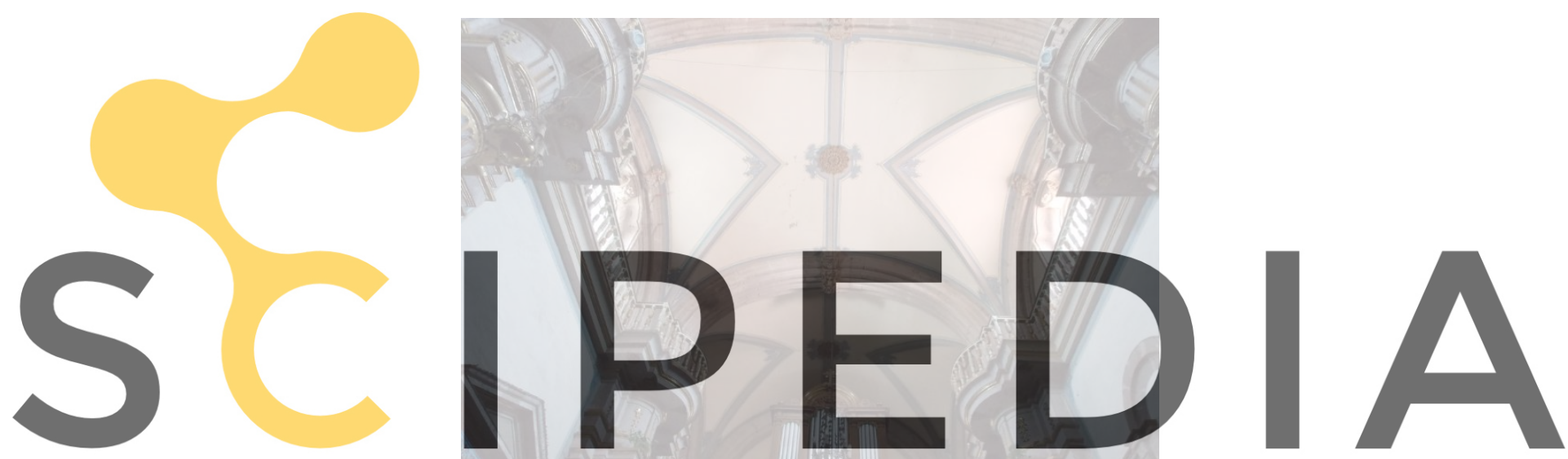

Figure 4: Nave chorus and lunette vaults stiffened with rib arches

\section{EXISTING DAMAGE}

The church of La Merced presents different damages, which, qualitatively, can be related more to seismic action than to another type of action, since the building was built on a stiff clay which reduces the risk of ground settlement, situation which is verified in neighboring buildings, which also do not present problems due to the service limit state.

\subsection{East façade damage}

It presents slight damage composed by a shear crack caused by the interaction of the facade with the bell tower, which starts from the upper corner of the coral window and extends vertically as shown in Figure 6. 

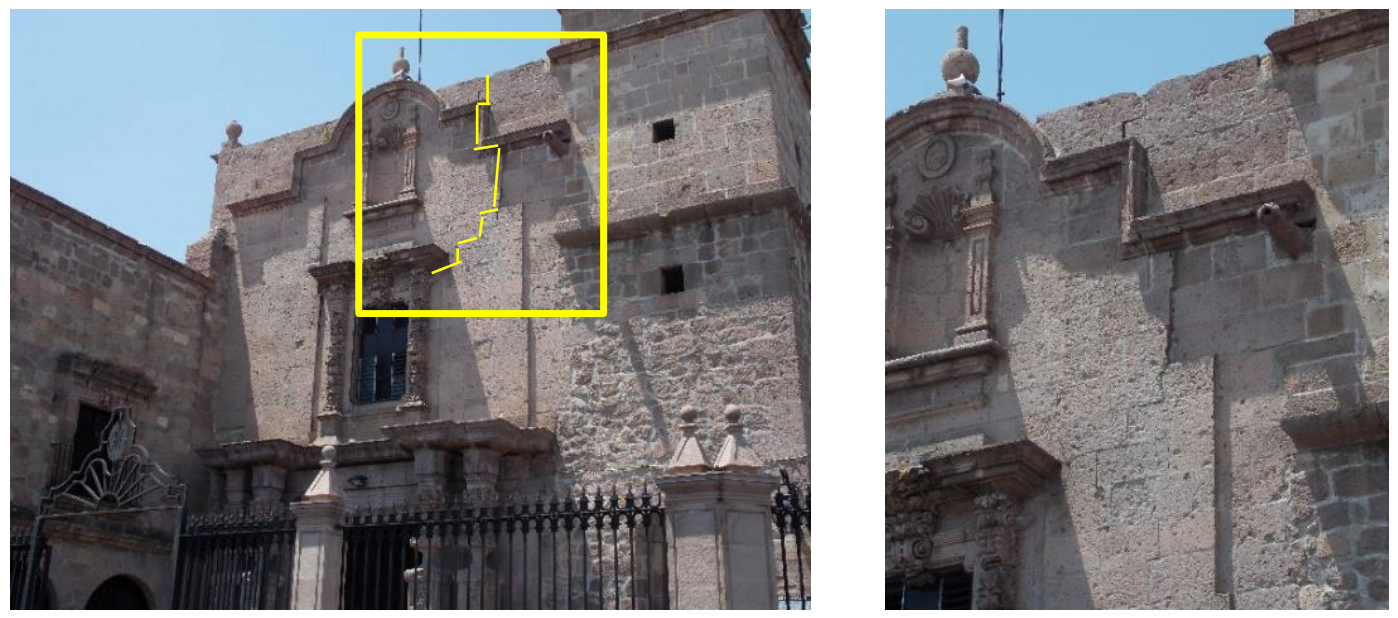

Figure 6: Main façade damage

\subsection{Ribbed dome damage}

The dome has cracks in each of its eight shells between ribs as shown in Figure 7. The cracks reach the lantern ring, damage that can also be attributed to past seismic actions. On the outside, the rocking effect of the pinnacles that are located on the drum ornamentation is evident, some of which have failed due to shear as indicated in Figure 8. Without any doubt, the pinnacles

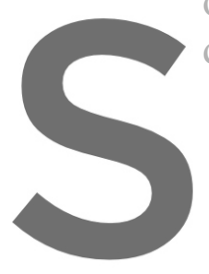
damages has been caused by hist
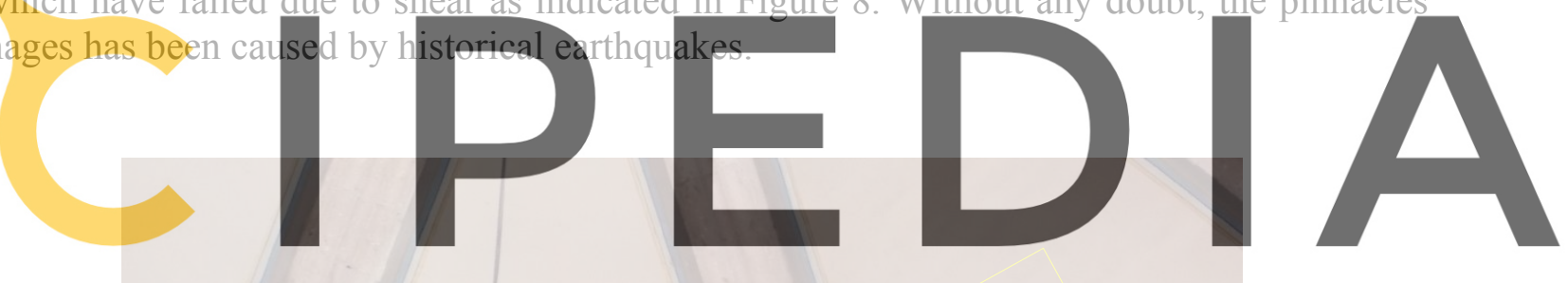

Register for free at https//www.scipedia.com to download the version without the watermark

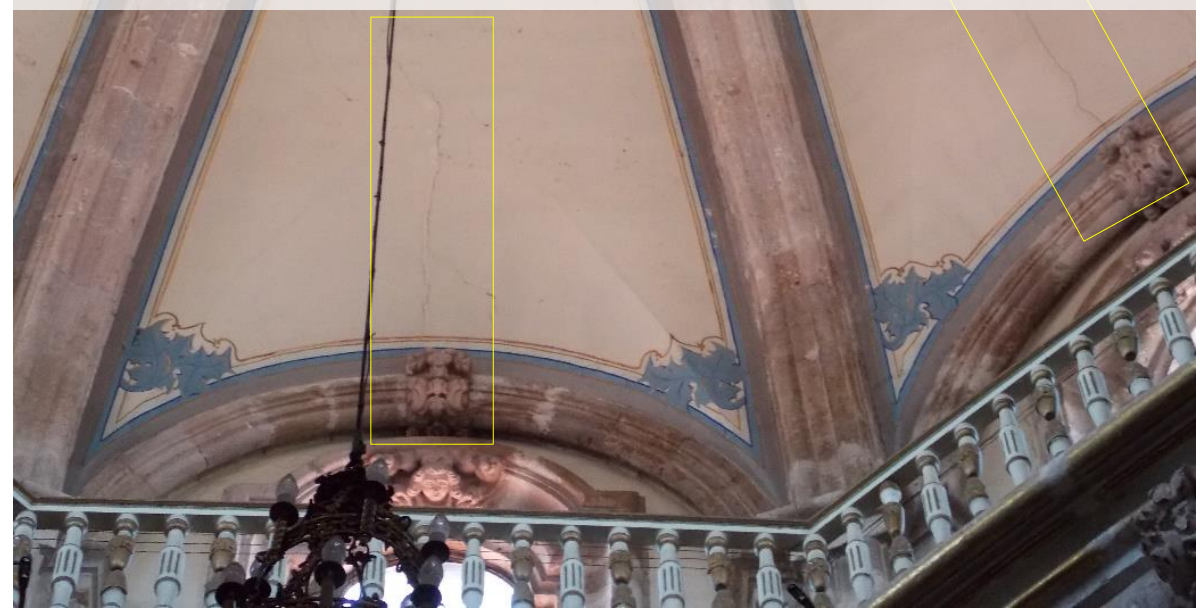

Figure 7: Cracks on the masonry dome 

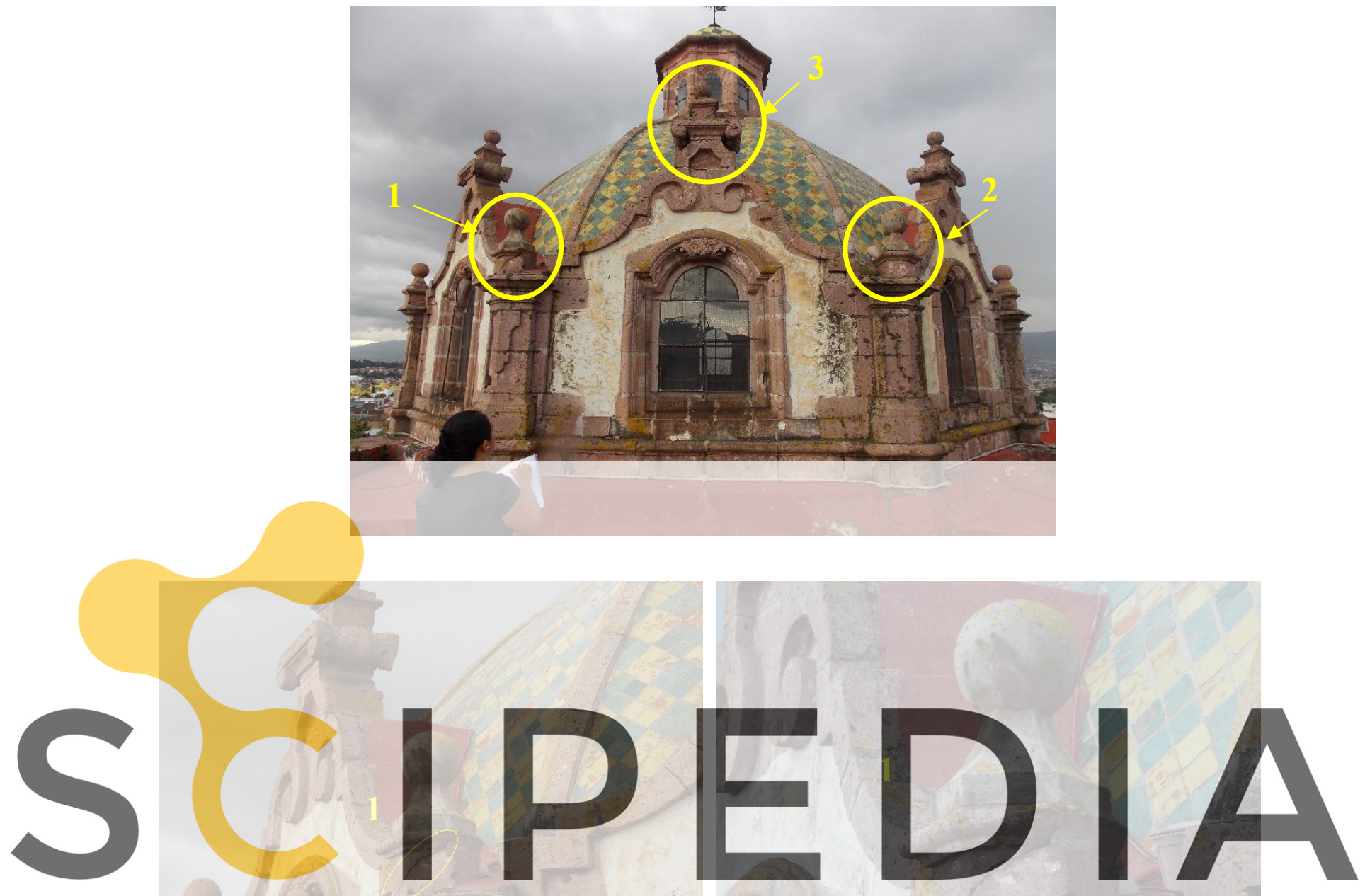

Register for free at https//www.scipedia.com to download the version without the watermark
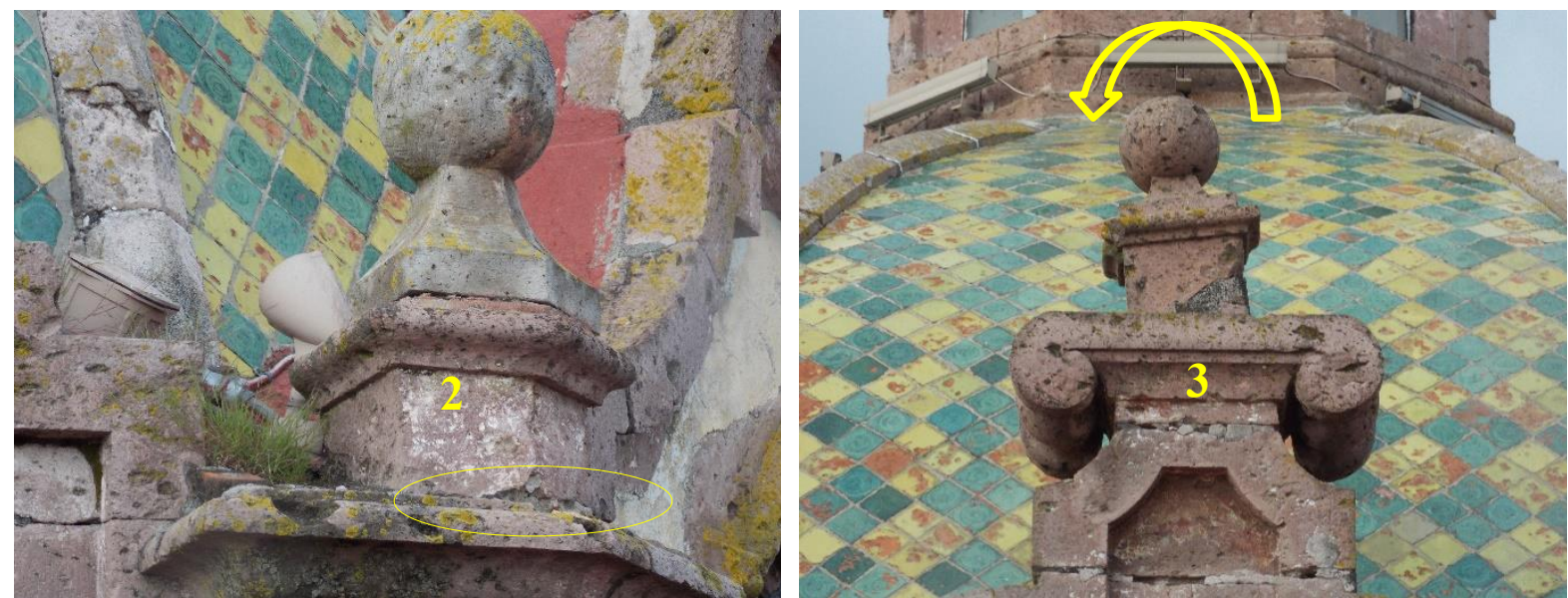

Figure 8: Pinacles rocking and shear base damages 


\subsection{Nave vault damages}

The lunette nave vaults have Sabouret cracks, Figure 9, as well as shear cracks that have practically been connected to each other in such a way that they can form rigid blocks that could become unstable in future seismic events of importance as seen in the Figure 10. It is also clear that such damage patterns can be associated without major error to the seismic action of the past.
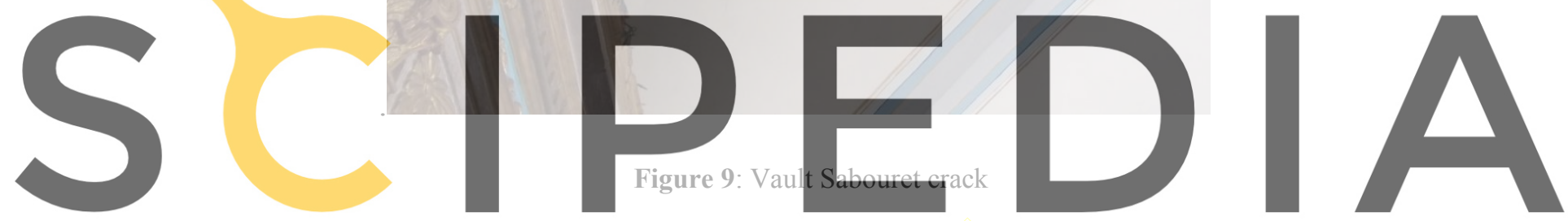

Register for free at https//www.scipedia.com to download the version without the watermark

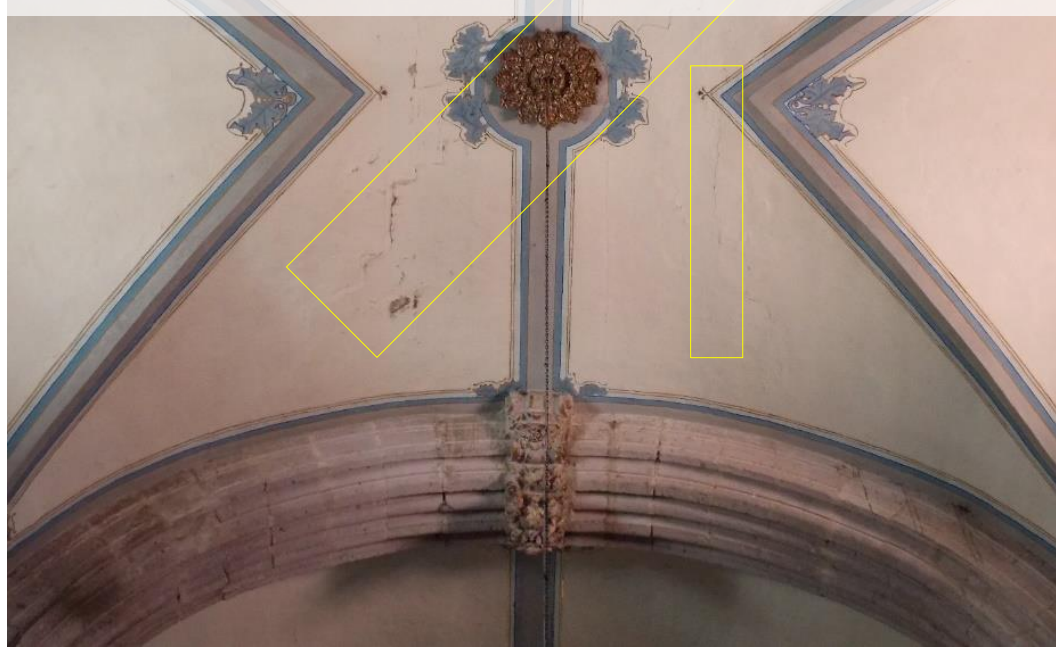

Figure 10: Main nave vault cracks 


\subsection{Rib arches damage}

These arches are $0.96 \mathrm{~m}$ wide and $0.40 \mathrm{~m}$ height. One of these arches shows damage to the intrados of one of it's kidneys as shown in Figure 11a, so a safety mesh has been placed to prevent damage to people who come to church every day. These arches have also lost their mortar joints between dowels and in recent years mortar injections have been made to consolidate them as shown in Figure 11b. Subjectively, it is not clear whether the damages observed could have been caused by seismic action.
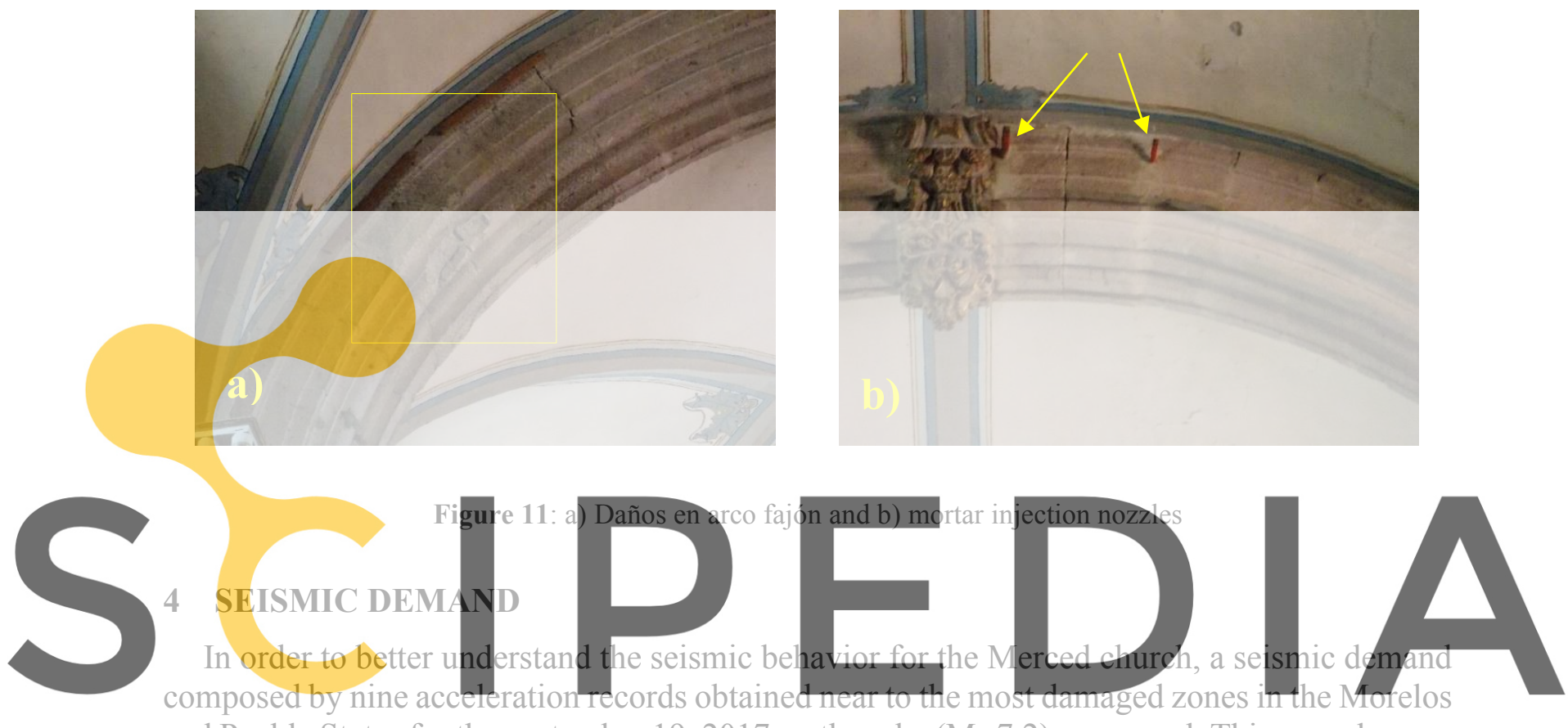

and Puebla States for the september 19, 2017 earthquake (Ms 7.2) were used. This records were

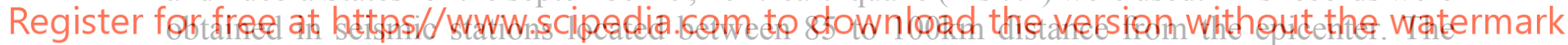

normal focal mechanism of this seismic event produced spectral amplifications in a range of periods of 0.18 to 0.54 seconds, reaching a maximum pseudoacceleration value of $1.01 \mathrm{~g}$ for a 0.44 seconds vibration period, Figure 12.

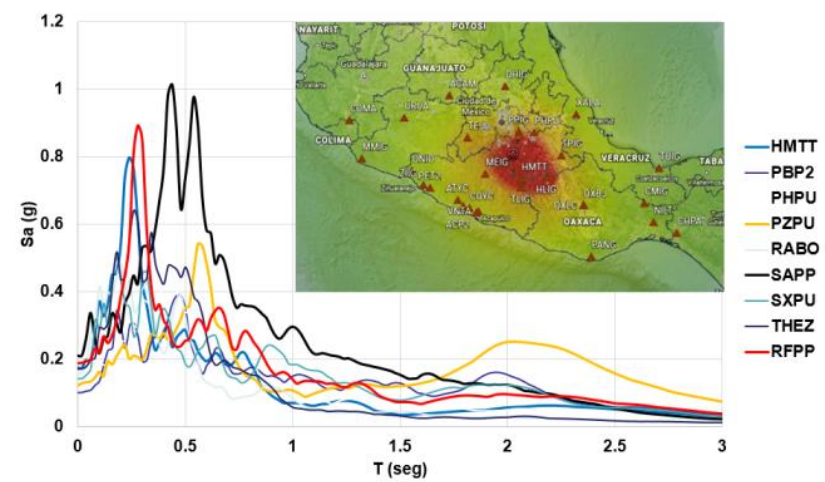

Figure 12: Response spectra of the nine highest peak ground accelerations (Seismic stations Map from the UNAM Engineering Institute) 


\section{SEISMIC BEHAVIOUR}

Two-dimensional Rigid Element macroelements were analyzed [2] for which the horizontal ground seismic shaking component was considered in a first stage, and in a second stage, the horizontal component acting simultaneously with the vertical component of the seismic record were applied, both in the transverse and longitudinal directions of the nave. The seismic demand was introduced with its original acceleration amplitudes and then scaling these amplitudes to the maximum probabilistic 475 and 975 year recurrence peak ground accelerations, that is, for 96.9 and 139.24gals.

\subsection{Macroelement definition}

Figure 13 shows the macroelements considered in the analysis; in the longitudinal direction is the located over the nave south wall and in the transverse direction the one corresponding to the nave connected to an existing flying arch, which, at the moment is inserted in the two old cloister levels of the David G. Berlanga elementary school. This macroelement was considered due to it has a high stiffness wich can concentrate major damages.
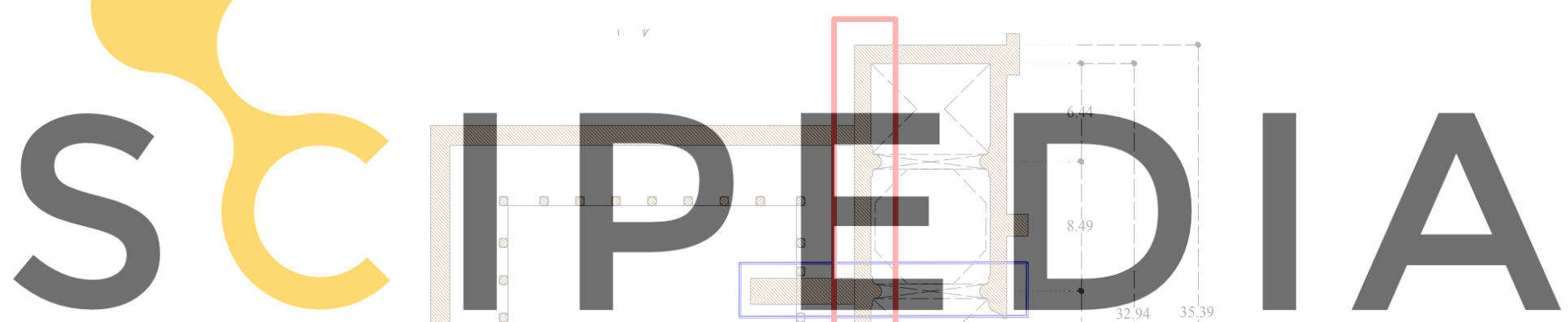

Register for free at https//wwaw.scipedia.com to download the version without the watermark

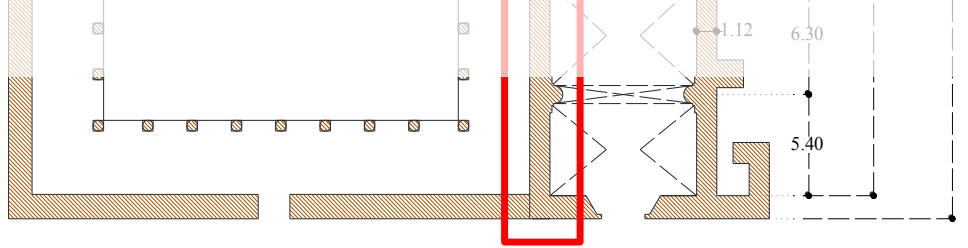

Figure 13: Macroelement definition. Transversal macroelement (blue) and longitudinal macroelement (red)

a)

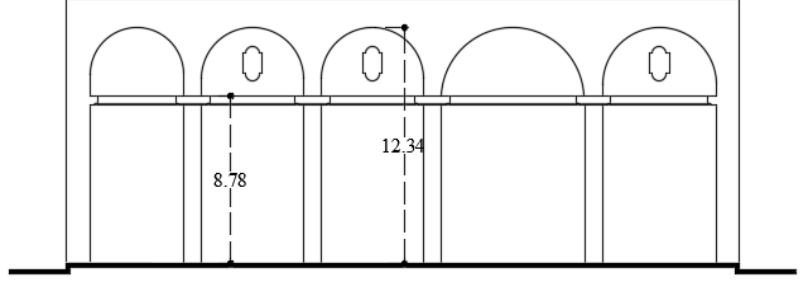

b)

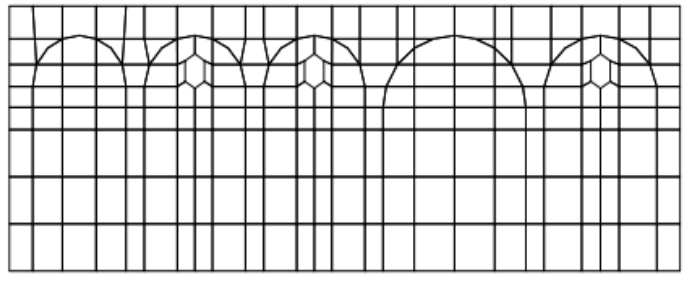

Figure 14: a) Longitudinal macroelement and b) Rigid element mesh 
a)

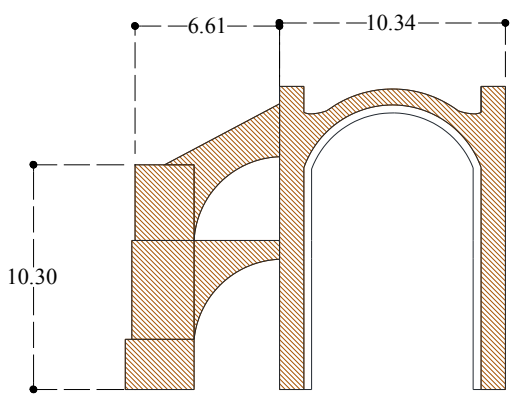

b)

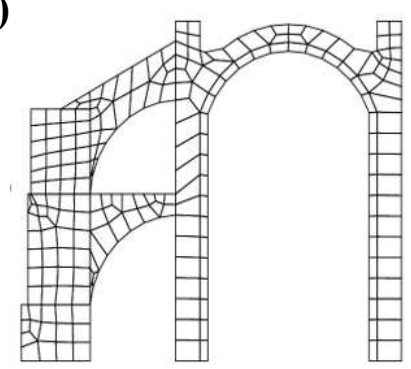

Figure 14: a) Longitudinal macroelement and b) Rigid element mesh

\subsection{Constituve model}

An exponential constitutive model was used for nonlinear analysis [3], in which the compression behavior is defined only by the initial stiffness of the material and the maximum compression strength as indicated in Table 1.

Table 1: Constitutive model parameters
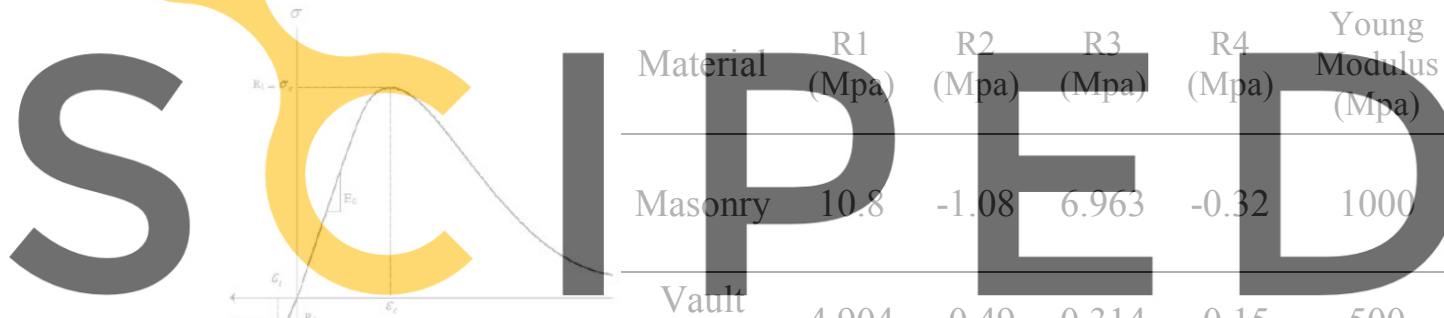

infill

4.904

$-0.49 \quad 0.314$

$-0.15$

500

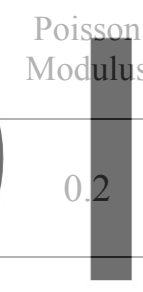

0.2

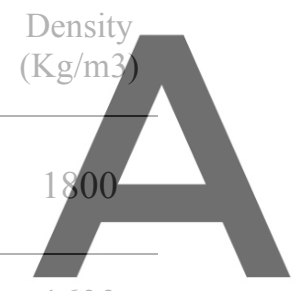

1600

Register for free at https//www.scipedia.com to download the version without the watermark

\subsection{Longitudinal macroelement}

The longitudinal macroelement has a high resistance and a high lateral stiffness as shown in Figure 15, and for the whole seismic demand no damages were obtained, so that the considered seismic demand does not cause any traction, compression or shear damages.

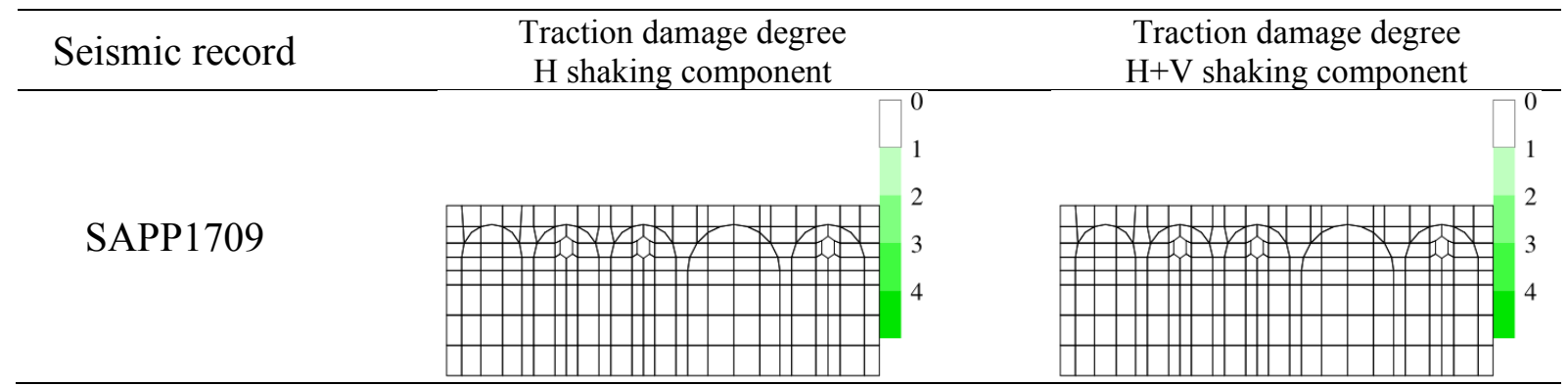

Figure 15: Longitudinal macroelement traction damage for one of the seismic records 


\subsection{Transversal macroelement}

In the nave transverse direction, the structural behavior was similar for all the considered seismic demand in terms of damage distribution, with moderate to extensive damage degrees at the key and springers of the vaults and arches. Such damages can be associated to the crack pattern observed in the vaults, and it is appreciated that the damage pattern does not change significantly when the earthquake vertical component is involved in the analyses, attributing such a situation to the reduced span of the nave of only $6.69 \mathrm{~m}$.

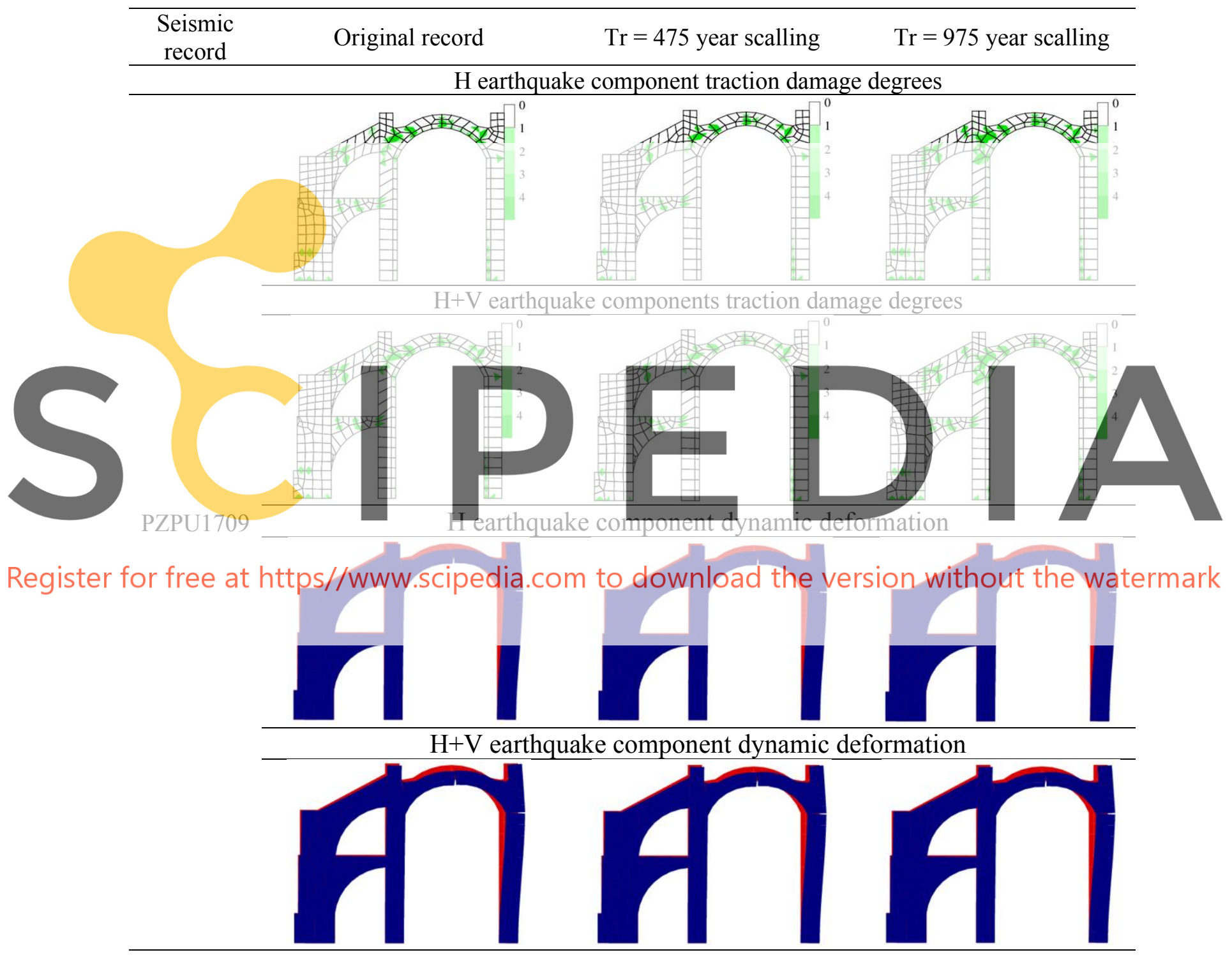

Figure 16: Transversal macroelement traction damages and dynamic deformations

The maximum lateral displacements are indicated in Table 2 for the considered seismic demand, finding that the greatest differences between introducing only one or two components 
of the earthquake ground shaking were only $13 \%$ of surplus and $7 \%$ in the opposite case. Therefore, for this particular church, the vertical component was favorable in introduce earthquake compression loads on the elements, which tended to close the produced cracks. For the Rigid program, values with zero displacement equal compression failure in some zone of the structure, which indicates that the maximum displacement that the temple vault can tolerate is less than or equal to $0.663 \mathrm{~cm}$.

Table 2: Transversal macroelement lateral displacements

\begin{tabular}{ccccccc}
\hline \multirow{2}{*}{$\begin{array}{c}\text { Seismic } \\
\text { Record }\end{array}$} & \multicolumn{2}{c}{$\begin{array}{c}\text { Original record } \\
(\mathrm{cm})\end{array}$} & $\mathrm{Tr}=475$ year scalling & \multicolumn{2}{c}{$\begin{array}{c}\mathrm{Tr}=975 \text { year scalling } \\
(\mathrm{cm})\end{array}$} \\
\cline { 2 - 7 } & $\mathrm{H}$ & $\mathrm{H}+\mathrm{V}$ & $\mathrm{H}$ & $\mathrm{H}+\mathrm{V}$ & $\mathrm{H}$ & $\mathrm{H}+\mathrm{V}$ \\
\hline HMTT1709 & 0.274 & 0.255 & 0.163 & 0.158 & 0.234 & 0.233 \\
\hline PBP21709 & 0.240 & 0.257 & 0.463 & 0.491 & 0.000 & 0.000 \\
\hline PHPU1709 & 0.506 & 0.503 & 0.319 & 0.318 & 0.000 & 0.000 \\
\hline PZPU1709 & 0.438 & 0.424 & 0.265 & 0.265 & 0.604 & 0.601 \\
\hline RABO1709 & 0.282 & 0.278 & 0.178 & 0.207 & 0.261 & 0.000 \\
\hline RFPP1709 & 0.429 & 0.380 & 0.206 & 0.205 & 0.274 & 0.275 \\
\hline SAPP1709 & 0.663 & 0.658 & 0.572 & 0.559 & 0.000 & 0.000 \\
\hline SXPU1709 & 0.168 & 0.172 & 0.151 & 0.161 & 0.233 & 0.221 \\
\hline THEZ1709 & 0.476 & 0.489 & 0.379 & 0.389 & 0.468 & 0.000 \\
\hline
\end{tabular}

Regarding the dissipated hysterical energy in the structure for the seismic demand without scaling and with scaling, Table 3 shows a small variation between the horizontal component exclusively and the combination of the horizontal with the vertical shaking. The greatest differences were found for the scaled 475 year recurrence with an $8.88 \%$ value, so it is verified that the dissipated hysterical energy differences were small. The zero value again implies compression failure in some macroelement area.

Table 3: Transversal macroelement histeretic disipated energy

\begin{tabular}{ccccccc}
\hline \multirow{2}{*}{$\begin{array}{c}\text { Seismic } \\
\text { Record }\end{array}$} & \multicolumn{2}{c}{$\begin{array}{c}\text { Original record } \\
(\mathrm{J})\end{array}$} & \multicolumn{2}{c}{$\mathrm{Tr}=475$ year scalling } & \multicolumn{2}{c}{$\begin{array}{c}\mathrm{Tr}=975 \text { year scalling } \\
(\mathrm{J})\end{array}$} \\
\cline { 2 - 7 } & $\mathrm{H}$ & $\mathrm{H}+\mathrm{V}$ & $\mathrm{H}$ & $\mathrm{H}+\mathrm{V}$ & $\mathrm{H}$ & $\mathrm{H}+\mathrm{V}$ \\
\hline HMTT1709 & $4.16 \mathrm{E}+05$ & $4.19 \mathrm{E}+05$ & $1.45 \mathrm{E}+05$ & $1.67 \mathrm{E}+05$ & $2.93 \mathrm{E}+05$ & $3.19 \mathrm{E}+05$ \\
\hline PBP21709 & $8.06 \mathrm{E}+05$ & $8.66 \mathrm{E}+05$ & $1.35 \mathrm{E}+06$ & $1.47 \mathrm{E}+06$ & $0.00 \mathrm{E}+00$ & $0.00 \mathrm{E}+00$ \\
\hline PHPU1709 & $5.55 \mathrm{E}+05$ & $5.27 \mathrm{E}+05$ & $3.08 \mathrm{E}+05$ & $2.98 \mathrm{E}+05$ & $0.00 \mathrm{E}+00$ & $0.00 \mathrm{E}+00$ \\
\hline PZPU1709 & $1.17 \mathrm{E}+06$ & $1.15 \mathrm{E}+06$ & $6.79 \mathrm{E}+05$ & $6.85 \mathrm{E}+05$ & $1.79 \mathrm{E}+06$ & $1.78 \mathrm{E}+06$ \\
\hline RABO1709 & $7.58 \mathrm{E}+05$ & $7.07 \mathrm{E}+05$ & $3.04 \mathrm{E}+05$ & $3.73 \mathrm{E}+05$ & $6.28 \mathrm{E}+05$ & $0.00 \mathrm{E}+00$ \\
\hline RFPP1709 & $7.39 \mathrm{E}+05$ & $6.22 \mathrm{E}+05$ & $3.24 \mathrm{E}+05$ & $3.25 \mathrm{E}+05$ & $5.06 \mathrm{E}+05$ & $5.07 \mathrm{E}+05$ \\
\hline SAPP1709 & $8.59 \mathrm{E}+05$ & $8.51 \mathrm{E}+05$ & $6.58 \mathrm{E}+05$ & $6.54 \mathrm{E}+05$ & $0.00 \mathrm{E}+00$ & $0.00 \mathrm{E}+00$ \\
\hline SXPU1709 & $1.85 \mathrm{E}+05$ & $2.07 \mathrm{E}+05$ & $1.76 \mathrm{E}+05$ & $1.85 \mathrm{E}+05$ & $2.74 \mathrm{E}+05$ & $2.94 \mathrm{E}+05$ \\
\hline THEZ1709 & $6.68 \mathrm{E}+05$ & $5.32 \mathrm{E}+05$ & $3.77 \mathrm{E}+05$ & $3.78 \mathrm{E}+05$ & $7.18 \mathrm{E}+05$ & $0.00 \mathrm{E}+00$ \\
\hline
\end{tabular}

To have a better damage degree indicator in the transverse direction of the nave, Table 4 shows the damage index (D) for the considered seismic demand without scaling and with scaling, which were calculated using the Park, Ang and Wen [4] formulation for masonry structures: 


$$
D=\frac{U_{m}}{U_{f}}+\frac{\varepsilon}{q_{u} * U_{f}} \int d E
$$

Where: $U_{m}$ is the maximum response deformation, $\int d E$ the incremental dissipated hysteretic energy, $U_{f}$ is the ultimate deformation capacity under monotonic loading, $q_{u}$ the yield strenght and $\varepsilon$ a non-negative experimental constant equal to 0.075 . The damage index is a normalized amount, whose value is, by definition, between 0 and 1 . The value of $\mathrm{D}$ equal to zero denotes an undamaged structure, that is, the linear elastic behavior of the structure during the earthquake, while a value greater than or equal to 1 denotes the failure of the structure, that is, local or general collapse of the structure.

Table 4: Damage Index (D) for the transversal macroelement

\begin{tabular}{ccccccc}
\hline \multirow{2}{*}{$\begin{array}{c}\text { Seismic } \\
\text { Record }\end{array}$} & \multicolumn{2}{c}{ Original record } & \multicolumn{2}{c}{$\mathrm{Tr}=475$ year scalling } & \multicolumn{2}{c}{$\mathrm{Tr}=975$ year scalling } \\
\cline { 2 - 7 } & $\mathrm{H}$ & $\mathrm{H}+\mathrm{V}$ & $\mathrm{H}$ & $\mathrm{H}+\mathrm{V}$ & $\mathrm{H}$ & $\mathrm{H}+\mathrm{V}$ \\
\hline HMTT1709 & 1.90 & 1.78 & 1.07 & 1.05 & 1.59 & 1.59 \\
\hline PBP21709 & 1.91 & 2.05 & 3.57 & 3.81 & 1.00 & 1.00 \\
\hline PHPU1709 & 3.38 & 3.35 & 2.11 & 2.10 & 1.00 & 1.00 \\
\hline PZPU1709 & 3.32 & 3.22 & 1.99 & 2.00 & 4.68 & 4.65 \\
\hline RABO1709 & 2.14 & 2.08 & 1.25 & 1.47 & 1.94 & 1.00 \\
\hline RFPP1709 & 3.02 & 2.66 & 1.44 & 1.43 & 1.95 & 1.96 \\
\hline SAPP1709 & 4.51 & 4.47 & 3.84 & 3.39 & 1.00 & 1.00 \\
\hline SXPU1709 & 1.12 & 1.16 & 1.02 & 1.08 & 1.57 & 1.51 \\
\hline THEZ1709 & 3.27 & 3.26 & 2.51 & 2.57 & 3.24 & 1.00 \\
\hline
\end{tabular}

\section{CONCLUSIONS}

La Merced church in Morelia city, Mexico, has a high strength and stiffness in their longitudinal walls and did not show any damage against the seismic demand produced by the September 19, 2017 earthquake, however, in its transverse direction, the nave would suffer local or global collapse before this seismic demand with and without scaling factors, which derives in a critical scenario for the building in the future since there are currently slight damages that would undoubtedly increase. With the above, it is essential to take urgent structural measures for the church, in order to achieve an adequate future seismic performance of this structure listed as a World Heritage Site since 1991 by UNESCO and thus avoid any social or cultural loss.

\section{REFERENCES}

[1] León, R. Los orígenes del clero y la iglesia en Michoacán, 1525-1640. Colección Histórica Nuestra No. 16, Instituto de Investigaciones Históricas, Universidad Michoacana de San Nicolás de Hidalgo, in Spanish, (1997).

[2] Casolo S. and Peña F. Rigid element model for in-plane dynamics of masonry walls considering hysteretic behaviour and damage, Earthquake Engineering and Structural Dynamics (2007), 36: 1029-1048. 
[3] Peña, F. RIGID (v.0.4.1) Programa de Elementos Rígidos para en Análisis Dinámico no Lineal de Estructuras de Mampostería, Instituto de Ingeniería, Universidad Nacional Autónoma de México, México (2010).

[4] Y. J. Park, Y.J., A. H-S. Ang, A. H-S., and Wen, Y.K. Damage-Limiting Aseismic Design of Buildings. Earthquake Spectra (1987), 3:1, 1-26. 